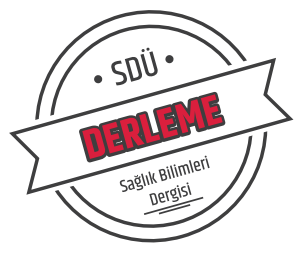

Sdü Sağlık Bilimleri Enstitüsü Dergisi / Cilt 8 Sayı 3 / 2017

\title{
Okul Öncesi Çocuklarda Oral Mukozal Premalign Durumlar ve Teşhis Yöntemleri
} Oral Mucosal Premalign Conditions and Diagnostic Methods in Preschool Children

Derya Ceyhan ${ }^{1}$, Canan Akdik ${ }^{1}$

${ }^{1}$ Süleyman Demirel Üniversitesi, Diş Hekimliği Fakültesi, Pedodonti AD, Isparta, Türkiye.

\section{Özet}

Oral kavite farklı histolojik yapısı ve işlevi bulunan dokulardan oluştuğundan benign, premalign ve malign karakterli lezyonlar ortaya çıkabilir. Malign karakterli olanlar, premalign olduğu düşünülen spesifik bir lezyondan köken alabilir. Normal dokuya göre maligniteye dönüşme riski daha yüksek olan oral premalign lezyonlar erken teşhis edildiği zaman malign transformasyon riski azalır ve büyüme-gelişim döneminde olan çocuklar daha basit yöntemler ile tedavi edilebilir. Pedodontistler ve çocuk hastaları tedavi eden diş hekimleri, okul öncesi çocuklarda oral bölgenin premalign lezyonlarının erken teşhisinde ve gerekli tedaviler için ilgili hekime yönlendirmede önemli rol oynar. Bu derlemede; okul öncesi çocuklarda görülebilen oral mukozal lezyonlar premalign olma durumu açısından değerlendirilerek klinisyenlere konu ile ilgili bir yol haritası sunulmaya çalışıldı. Erken teşhis ve uygun yaklaşımlar, hastalıkların prognozunda ve hastaların yaşam kalitesinde olumlu sonuçlar ortaya çıkaracaktır.

Anahtar kelimeler: Çocuk Hasta, Diş Hekimliği, Oral Premalign Lezyon, Teşhis

\begin{abstract}
Benign, premalignant and malignant lesions could arise due to different histological structures and functional tissues of the oral cavity. Malignant lesions may derive from specific premalignant lesions. When oral premalignant lesions which have greater risk than normal tissues for malignant transformation, are diagnosed early, malignant transformation risk will decrease and children in growth and development period could be treated with simpler methods. Pediatric dentists or dentists treating children play an important role in early diagnosis and treatment planning of oral premalignant lesions in preschool children. In this paper, oral mucosal lesions in preschool children are reviewed in terms of premalignancy, and a route map about diagnosis and approaches is tried to represent for clinicians. Early diagnosis and appropriate approaches will reveal positive results on the prognosis of diseases and the life quality of patients.
\end{abstract}

Keywords: Pediatric Patient, Dentistry, Oral premalignant lesion, Diagnosis

\section{Giriş}

Ağız sağlığ1 bireylerin yaşam kalitesini etkileyen önemli bir faktördür. Çocukluk döneminde de karşılaşılan oral lezyonlar; konuşma, çiğneme ve yutma sırasında ağrıya sebep olabileceği gibi duyu kaybına, ağız kuruluğuna veya ağız kokusuna sebep olarak da günlük aktiviteleri engeller ve yaşam kalitesini düşürür.

Oral lezyonların bir bölümü sadece ağız kaynaklı iken diğer bölümü sistemik bir hastalığın oral bulgusudur. Premalignmalign hastalıkların habercisi de olabilen oral lezyonlar, oral mukozadaki bulguların gözden kaçırılması veya yorumlanamaması nedeniyle teşhis koyulmasında gecikmeye, dolayısıyla da lezyonun ilerlemesine sebep olabilir. Doğru ve erken teşhis ve yaklaşımlar, hastalıkların prognozunu olumlu yönde etkiler.

Bu derlemede; okul öncesi çocuklarda görülen oral mukozal lezyonları premalign olma durumu açısından ele alarak bilgileri güncellemek, klinisyen yaklaşımı açısından bir rehber oluşturmak ve hastalıkların erken teşhisine yardımcı olmak amaçlandi.

\section{Oral Mukozal Lezyonlar}

Oral kavite farklı histolojik yapı ve işlevdeki dokulardan oluşur, bu doku çeşitliliği de farklı lezyonların ortaya çıkmasına neden olur. Bu lezyonlar etiyolojik olarak siniflanabileceği gibi morfolojik özelliklerine göre de sinıflanabilir. Etiyolojik özelliklerine göre otoimmün inflamatuar, enfeksiyöz inflamatuar ve sistemik hastalıkların oral bulguları olarak, morfolojik özelliklerine göre ise vezikülöbüllöz hastalıklar, ülseratif hastalıklar, beyaz lezyonlar, kırmızı-mavi lezyonlar, oral bölgenin pigmentasyonları, verrüköz-papiller lezyonlar şeklinde sınıflanmıştır $(1,2,3)$. Oral mukozada görülen lezyonlar için kullanılabilecek genel sınıflama, temel başlıklar halinde Tablo 1'de sunulmuştur (3).

Temel başliklar halinde belirtilen oral mukoza lezyonlarından premalign karakterli olanları sunmak, klinisyenlerin bu lezyonlara yaklaşımı, hastaları erken dönemde ilgili hekime
DOI: 10.22312 /sdusbed. 377433

Müracaat tarihi: 15.11 .2016

Kabul tarihi: 10.04 .2017

\footnotetext{
Yazışma Adresi / Corresponding: Derya Ceyhan, Süleyman Demirel Üniversitesi, Diş Hekimliği Fakültesi, Pedodonti AD, Isparta, Türkiye. Tel: 02462118837

Fax: 02462370607

E-mail: derya_ceyhan@yahoo.com
} 
yönlendirmeleri ve malign transformasyonun önlenmesi ve sınırlandırılması açısından önem taşımaktadır.

Tablo 1. Oral mukozada görülen lezyonlar için yaygın olarak kullanilan siniflama (3)

\section{Mukozal lezyonlar}

\begin{tabular}{cc}
\hline Vezikülobüllöz hastalıklar & Gingival şişlikler \\
\hline Ülseratif lezyonlar & Ağız tabanındaki şişlikler \\
\hline Beyaz lezyonlar & Dildeki şişlikler \\
\hline Kırmızı-mavi lezyonlar & $\begin{array}{c}\text { Dudak ve bukkal mukozadaki } \\
\text { şişlikler }\end{array}$ \\
\hline Pigmente lezyonlar & Palatal bölgedeki şişlikler \\
\hline Verrüközpapiller lezyonlar & Boyun bölgesindeki şişlikler \\
\hline
\end{tabular}

\section{Oral Mukozal Premalign Lezyonlar}

Malignite potansiyeli olan lezyonlar için 'premalign', 'prekanseröz', 'potansiyel malign', 'intraepitelyal neoplazi' terimleri kullanılır. Bu lezyonlar, morfolojik, histolojik ve genetik olarak değişime uğramış ve normal dokuya göre maligniteye dönüşme riski daha yüksek olan lezyonlar olarak tanımlanır $(4,5)$. Baş boyun bölgesinde karsinojen ile ilk kez karşılaşıldığında tüm mukozada moleküler değişiklikler olur ve alan kanserizasyonu oluşur $(4,6,7)$. Alan kanserizasyonu, premalign oluşumlardan güçlü malign değişimlere uzanan epitelyal değişiklikleri içerir (7). Beslenme yetersizliği, genetik yatkınlığı ve human papilloma virüsü olan kişilerin premalign lezyonlar açısından yüksek risk grubunu oluşturduğu belirtilmiştir (7).

Pedodontistler ve çocuk hastaları tedavi eden diş hekimleri, bebeklik çağından itibaren çocukların ağız-diş sağlığını ve çene-yüz bölgesi gelişimini takip ettiklerinden okul öncesi çocuklarda oral bölgenin premalign-malign lezyonlarının erken teşhisinde önemli rol oynar ve yüksek risk grubu hastaları belirleyip konsültasyona yönlendirmede büyük katkı sağlayabilir.

Bugüne kadar yapılan çalışmalar daha çok yetişkinlere yönelik olup okul öncesi çocuklarda görülen oral mukozal premalign lezyonlar ve teşhisleri ile ilgili herhangi bir kaynağa ulaşılamamıştır. Genç erişkin ve yetişkin bireylerde karşılaşılan premalign oral mukozal lezyonlar; Lökoplaki, Eritroplaki, Liken planus, Submuköz fibrozis, Nikotin stomatiti, Xeroderma pigmentozum, Keratoakantoma, Aktinik şelitis, Sublingual keratoz, Tütün hiperkeratozları ve Otoimmün yetmezlik Sendromu olarak bildirilmiştir (8). Okul öncesi çocuklarda görülebilen premalign durumlar ise Epidermolizis Bülloza, Witkop Hastalığı, Kondiloma Aküminatum, Mukozal Nöroma ve Konjenital Diskeratozis'tir (9).

\section{Konjenital Diskeratozis}

Deride atrofi ve pigmentasyon, tırnak distrofisi, müköz membranlarda lökoplaki, kemik iliği yetersizliği ve maligniteye yatkınlık ile karakterize, nadir görülen, çoğunlukla X'e bağlı resesif, ciddi, multisistemik bir hastalık olup patogenezi ve etiyolojisi bilinmemektedir. Teşhisinde anamnez ve klinik bulgular önem taşır. Hastalığın başlangıcı, yaşamın ilk yıllarıdır. Deri ve mukoza bulguları dışında dental, oftalmolojik, nörolojik, hematolojik, gastrointestinal ve genitoüriner belirtiler de görülebilir. Mukoza lezyonları diğer klinik bulgular ile beraber ortaya çıkar veya 2 . ve 3 . dekata kadar klinik bulgu vermeyebilir. Diş çürümesi, dişeti hastalıkları, diş kaybı oldukça sık görülür $(10,11,12)$.

Yassı hücreli karsinom riski nedeniyle hastanın ağız içi acil tedavileri yapılarak donanımlı bir sağlık kurumuna yönlendirilmelidir. Ayırıcı tanıda Rothmund-Thomson sendromu ve anhidrotik ektodermal displazi göz önünde bulundurulmalidir $(11,12)$.

\section{Mukozal Nöroma}

Dilde şişlik şeklinde görüntü veren, nadir görülen, otozomal dominant bir hastalık olup medullar tiroid karsinoma oranının yüksek olduğu, tipik bir fiziksel görünüm ve çoklu mukozal nöromalarla karakterizedir. Teşhisinde ayrıntılı anamnez ve klinik bulgular önem taşır. Biyopsi, ultrasonografi, manyetik rezonans görüntüleme ve optik koherens tomografi (13) lezyonun teşhisinde kullanılan yöntemlerdir.

Mukozal nöromaların bebeklik döneminde oluşmaya başladığı bildirilmiştir (14). Hastalar kaba yüz görünümüne, kalın şişmiş dudaklara ve marfanoid özelliklere sahiptir ve kabızlık veya ishal görülebilir. Nöromalar; bukkal mukoza, dil, göz kapakları ve bağırsaklarda oluşur. Daha önce herhangi bir hekime başvurmamış ve ilk kez diş hekimine gelen hastalarda, bu hastalığa ait bulguların diș hekimi tarafından farkedilip hastalığın malign duruma dönüşmeden önce teşhis edilmesi ve hastanın yönlendirilmesi önemlidir. Yaş, cinsiyet, hastalığın safhası ve boyutu, tedavinin tipi gibi faktörlerin hastalığın prognozunu etkilediği bildirilmiştir (15).

Hastaya oral hijyen motivasyonu verilerek acil tedavileri yapılmalı ve hastalığın kanserleşme eğiliminden dolayı vakit kaybetmeden ilgili hekime yönlendirme yapılmalıdır. Ayırıcı tanı, multiple endokrin neoplazi ile yapılmalıdır (15).

\section{Epidermolizis Bülloza}

Vezikülobüllöz bir hastalık olan Epidermolizis Bülloza, yassı epitel içeren dokularda bül ve erozyon oluşması ile karakterize bir grup kalıtımsal hastalığı tanımlar. Tüm rrksal ve etnik grupları etkileyebilmekte ve cinsiyet ayrımı görülmemektedir (16). Teşhisi; anamnez, klinik değerlendirme, vital doku boyama ve biyopsi materyalinin immünohistokimyasal, 1ş1k mikroskobu veya elektron mikroskobu değerlendirmesi ile yapılır. Sıklıkla doğumda veya yaşamın ilk yılı boyunca ortaya çıkan bu hastalık; Epidermolizis Bülloza Simpleks, Fonksiyonel Epidermolizis Bülloza ve Distrofik Epidermolizis Bülloza olmak üzere 3 ana kategoriye ayrılmıştır. Fonksiyonel Epidermolizis Bülloza, ciddi morbidite ve mortaliteye sahiptir (17). Ağızda, başta 
dil olmak üzere, yanak ve damakta hemorajik büller meydana gelebilir. Bu büller hızlıca erozyon ve ülserasyonlara dönüșür. Diş minesine etkisi hafif pit defektlerinden ciddi hipoplazi, zayıf mine yapısı veya mine kaybına kadar çeşitlilik gösterir (18).

Yaygın büller ve bu büllerin açılması ile oluşan yaralar enfeksiyon riski taşır, enfeksiyonlar hızla yayılarak mortaliteye neden olabilir, özellikle çocuk hastalarda deri kanserleri gelişerek hayatı tehdit edici bir tablo meydana gelebilir. Dolayısıyla ortaya çıkan büller, sıvı toplanmasını önlemek için steril bir iğne ile boşaltılmalı ve açık yaralar, petrol emdirilmiş gazlı bez, hidrojel gibi dokuya yapışmayan ajanlar ile örtülenmelidir (19). Hastaya yoğun bir oral hijyen motivasyonu verilmeli, sürekli plak kontrolü yapılmalı, diş tedavileri sırasında travmatik yaklaşımlardan kaçınılmalı (20) ve yapılan dolgular iyi cilalanmalı, keskin kenar birakılmamalı, hasta enfeksiyondan korunmalıdır (21). Ayırıcı tanıda göz önünde bulundurulması gerekli durumlar; konjenital ihtiyoziform eritrodermi, aplazia kutis konjenita, konjenitel herpes simpleks virüs enfeksiyonu ve stafilokoksik soyulmuş deri sendromudur (22).

\section{Witkop Hastalığı}

Beyaz lezyon olan, diş ve tırnak sendromu olarak da bilinen bu hastalık; diş, saç, tırnak, salg1 bezleri gibi ektodermden köken alan iki veya daha fazla yapının yokluğu veya azalmış fonksiyonu ile karakterize, kalıtımsal ektodermal displazinin bir formudur. A $\breve{g} ı$ mukozasında lökoplakiler görülebilir. Teşhisinde ayrıntılı anamnez ve klinik bulgular önem taşımaktadır. Öncelikle hipodonti ve tırnak displazisi ile seyreden bu sendromda hafif saç ve ter bezi displazileri görülebilir. Tırnaklar kaşık şeklinde, çıkıntılı, yavaş büyüyen ve kolayca kırılabilen bir yapıdadır. Kuru, hipopigmente bir deri görülmekle birlikte kronik ekzamatöz dermatitis de bulunabilir. Gözyaşı ve tükürük salgısında azalma meydana gelmektedir. Hipodonti veya anadonti, malforme, tam gelişmemiş veya çivi şeklinde dişler, mine defektleri ve diş çürükleri sık görülen dişsel bulgulardır. Süt dişlerindeki defektler hafif olup daimi dişler sürene kadar herhangi bir anomali izlenmemektedir $(23,24)$.

Hastalığın ciddi boyutlara ulaşarak enfeksiyon, lökoplaki ve kanserleşmeye neden olmaması için diş tedavileri sırasında Epidermolizis Bülloza'daki gibi travma ve enfeksiyonlardan koruma şeklinde bir yaklaşım sergilenmeli ve hastanın sistemik değerlendirilmesi için ilgili hekime yönlendirme yapılmalıdır. Ayırıcı tanıda hipofosfatazya, siklik nötropeni ve Papillon-Lefevre sendromu göz önünde bulundurulmalıdır $(24,25)$.

\section{Kondiloma Aküminatum}

Verrüközpapiller karakterde, çok katlı yassı epitelin proliferatif bir lezyonu olup direkt cinsel ve maternal yoldan, indirekt olarak tokalaşma, havlu, havuz ve tuvaletlerden bulaşan, servikal karsinoma oranının yüksek olduğu, sık görülen hastalıklardan biridir. Human papilloma virüsün (HPV) tiplerinin ürettiği, anogenital bölgenin ekzofitik, sapsız, belirgin sınırlı, ağrısız lezyonu olan zührevi siğillerdir. $\mathrm{Bu}$ lezyonların oral ve larenks mukozalarında görülmeleri de mümkündür (26). Teşhisinde ayrıntılı anamnez alınarak klinik bulgular değerlendirilmelidir. Oral eksfolyatif sitoloji, vital doku boyama ve optik koherens tomografi (13) lezyonun teşhisinde kullanılan yöntemlerdir. Ağız boşluğunda pempe, belirgin sınırlı olup labial mukoza, yumuşak damak ve lingual frenilumda görülür. Çocuk hastalarda nadiren görülen bu lezyonlara küçük yaşlarda rastlanabilir ve cinsel istismara işaret edebilir. Doğumda annelerinde genital siğil bulunan çocuklarda genital lezyonlardan önce oral lezyonlar ortaya çıkar (27).

Hastalığın karsinojen özelliği ve yayılma hızının yüksek olmasından dolayı aile bireyleri olası bulaş yolları ve nüksler hakkında bilgilendirilmeli, oral hijyen motivasyonu ve tedavileri takiben hasta bu konuda uzman bir hekime yönlendirilmelidir. Ayırıcı tanı kondiloma lata, oral verruka vulgaris ve fokal epitelyal hiperplazi ile yapılmalıdır (9).

\section{Oral Mukozal Premalign Lezyonların Teşhis Yöntemleri}

Oral mukozal premalign lezyonlar erken teşhis edildiği zaman malign transformasyon riski azalır, büyüme ve gelişim döneminde olan çocuklar daha fazla ilaç ve kombine tedaviler yerine daha basit yöntemler ile tedavi edilerek yaşamlarına devam edebilirler. Ancak, lezyonların gelişirken semptom vermemeleri ve belirgin mukozal değişiklikler yaratmamaları nedeniyle az sayıda olgu erken dönemde saptanır (4) ve olgular genellikle semptomatik hale geldiği zaman teşhis edilir (28).

Günümüzde ağız mukozasındaki epitelyal değişimleri saptamak için sıklıkla kullanılan yöntem anamnez, görsel muayene ve palpasyonun kombinasyonu olup premalignmalign lezyonların, klinik olarak benzer görünümlü benign lezyonlardan ayırt edilmesinde zorluklar ile karşılaşılır (29,30). Bu açıdan; oral mukoza muayenesini ayrıntılandırmak, oral benign, premalign ve malign lezyonları saptamak ve birbirinden ayırt etmeyi kolaylaştırmak amacıyla farklı teknikler kullanmak faydalı olacaktır.

\section{Anamnez}

Hastalıkların doğru teşhis edilebilmesi için hangi kriterlerin ölçü olarak kullanılacağı önemlidir. İyi bir anamnez ile hastanın geçmiş ve şu anki sosyal, ailesel, davranışsal, emosyonel, medikal ve dental hikayesi öğrenilmekte ve bu bilgiler teşhis-tedavi planlamasında kullanılmaktadır. Bir hastalığa doğru teşhis koyulması ve tedavinin gerektiği şekilde yapılabilmesi için anamnezin ayrıntılı bir şekilde alınması ve derinleştirilmesi oldukça önemlidir. Özellikle premalign bir lezyondan şüphelenildiğinde aile öyküsü, hamilelik hikayesi, doğum şekli, mevcut kalıtımsal ve genetik hastalıklar, sistemik hastalıklar (demir eksikliği anemisi, viral enfeksiyonlar vb.), ilaç kullanımı (immunsupresif vb.), radyasyona maruz kalma, vücudun diğer bölgelerinde herhangi bir bulgu olup olmadığı, lezyonun büyüme hızı, gösterdiği değişiklikler, yaşam kalitesi üzerine etkileri (solunum-yutkunma güçlüğü, tat alma bozukluğu, anestezi ve parestezi gibi nörolojik yakınmalar, ağrı, kanama, ateş, bulantı, kusma, iştahsızlık vb.) öğrenilmelidir. Lezyon bölgesine yönelik geçirilmiş travma hikayesi ile hastanın alışkanlıkları (yanak ısırma vb.) araştırılmalıdır. 


\section{Klinik Muayene}

Hekim ile çocuk hasta arasındaki iletişimi sağlayan basamaktır. Klinik muayene; genel değerlendirme, ekstraoral ve intraoral muayene ve radyografik muayeneleri içerir. Ekstraoral muayenede baş, yüz ve boyun muayenesi yapılır.

Genel değerlendirme bekleme odasında yapılabilir, bu sayede fiziksel bulgular ve herhangi bir anormal bulgu gözlenebilir, ebeveyn ve çocuk arasındaki ilişki ve ebeveyn hakkında da bilgi sahibi olunabilir.

Baş, yüz ve boyun muayenesinde saçlara, kafa derisine, kulaklara, gözlere, burna, dudaklara, temporomandibular ekleme, çene ucuna, lenf nodüllerine, tiroide ve cilde; intraoral muayenede damak ve ağız tabanına, dile, farinkse, bukkal mukozaya ve dișlere bakılır. Radyografik muayene, bazı çocukların uyum göstermemesinden dolayı çok gerekli olmayan durumlarda ertelenebilir.

Ağız içinde görülen bir enfeksiyon ve premalign olma durumu şüphesi için boyut, renk, 1sı değişikliği gibi özellikler değerlendirilmeli, lezyonun ortaya çıkış yeri ve zamanı, sayısı (tek ya da çok sayıda), çevre dokularla ilişkileri (hareketli, fikse), mukoza ile örtülü ise yüzey özellikleri (soluk, hiperemik, ülsere, vb.), ağrı veya herhangi bir rahatsızlık ve etrafindaki dokularda bir defekt veya anormal bir durum oluşturma durumları öğrenilmelidir.

Tablo 2. Okul öncesi çocuklarda oral mukozal premalign lezyonların özellikleri, teşhis yöntemleri, ayırıcı tanıları ve gerekli klinisyen yaklaşımları

\begin{tabular}{|c|c|c|c|c|c|c|c|}
\hline Hastalık & Etken & Bulaş Yolu & Teşhis Yöntemi & $\begin{array}{l}\text { Ağız } \\
\text { İçindeki } \\
\text { Lokali- } \\
\text { zasyon }\end{array}$ & Klinik Bulgular & Ayırıcı Tanı & $\begin{array}{l}\text { Gerekli Yak- } \\
\text { laşımlar }\end{array}$ \\
\hline $\begin{array}{l}\text { Konjenital } \\
\text { Diskeratozis }\end{array}$ & Genetik & & $\begin{array}{l}\text {-Anamnez } \\
\text {-Klinik muayene } \\
\text {-Vital doku } \\
\text { boyama }\end{array}$ & $\begin{array}{l}\text {-Dişler } \\
\text {-Dişeti }\end{array}$ & $\begin{array}{l}\text {-Diş çürükleri } \\
\text {-Dişeti hastalıkları } \\
\text {-Diş kayıpları }\end{array}$ & $\begin{array}{l}\text {-Roth- } \\
\text { mund-Thom- } \\
\text { son Sendromu } \\
\text {-Anhidrotik } \\
\text { Ektodermal } \\
\text { Displazi }\end{array}$ & $\begin{array}{l}\text {-Oral hijyen } \\
\text { motivasyonu } \\
\text {-Acil tedaviler } \\
\text {-Konsültasyon }\end{array}$ \\
\hline $\begin{array}{l}\text { Mukozal } \\
\text { Nöroma }\end{array}$ & Genetik & & $\begin{array}{l}\text {-Anamnez } \\
\text {-Klinik muayene } \\
\text {-Biyopsi } \\
\text {-Ultrasonografi } \\
\text {-MRG } \\
\text {-Optik koherens } \\
\text { tomografi }\end{array}$ & $\begin{array}{l}\text {-Dudaklar } \\
\text {-Bukkal } \\
\text { mukoza } \\
\text {-Dil }\end{array}$ & $\begin{array}{l}\text {-Kalın, şişmiş } \\
\text { dudaklar } \\
\text {-Kaba yüz } \\
\text { görünümü } \\
\text {-Marfanoid özel- } \\
\text { likler }\end{array}$ & $\begin{array}{l}\text {-Multiple } \\
\text { Endokrin Neo- } \\
\text { plazi (MEN) }\end{array}$ & $\begin{array}{l}\text {-Oral hijyen } \\
\text { motivasyonu } \\
\text {-Konsültasyon }\end{array}$ \\
\hline $\begin{array}{l}\text { Epidermoli- } \\
\text { zis Bülloza }\end{array}$ & Genetik & & $\begin{array}{l}\text {-Anamnez } \\
\text {-Klinik muayene } \\
\text {-Biyopsi }\end{array}$ & $\begin{array}{l}\text {-Dil } \\
\text {-Yanak } \\
\text {-Damak }\end{array}$ & -Hemorajik büller & $\begin{array}{l}\text {-Konjenital } \\
\text { Herpes Sim- } \\
\text { pleks } \\
\text {-Stafilokoksik } \\
\text { Soyulmus Deri } \\
\text { Sendromu }\end{array}$ & $\begin{array}{l}\text {-Oral hijyen } \\
\text { motivasyonu } \\
\text {-Uygun bitirilmiş } \\
\text { restorasyonlar } \\
\text {-Atravmatik teda- } \\
\text { vi yaklaşımları } \\
\text {-Konsültasyon }\end{array}$ \\
\hline $\begin{array}{l}\text { Witkop } \\
\text { Hastalığı }\end{array}$ & Genetik & & $\begin{array}{l}\text {-Anamnez } \\
\text {-Klinik muayene }\end{array}$ & $\begin{array}{l}\text {-Dişler } \\
\text {-Oral mukoza }\end{array}$ & $\begin{array}{l}\text {-Gözyaşı ve tükürük } \\
\text { salgısında azalma } \\
\text {-Hipodonti } \\
\text {-Kaşık tırnak }\end{array}$ & $\begin{array}{l}\text {-Hipofosfa- } \\
\text { tazya } \\
\text {-Siklik Nötro- } \\
\text { peni } \\
\text {-Papil- } \\
\text { lon-Lefevre } \\
\text { Sendromu }\end{array}$ & $\begin{array}{l}\text {-Oral hijyen } \\
\text { motivasyonu } \\
\text {-Atravmatik teda- } \\
\text { vi yaklaşımları } \\
\text {-Konsültasyon }\end{array}$ \\
\hline $\begin{array}{l}\text { Kondiloma } \\
\text { Aküminatum }\end{array}$ & $\begin{array}{l}\text { HPV } \\
\text { tipleri }\end{array}$ & $\begin{array}{l}\text {-Maternal yol } \\
\text {-Cinsel istismar } \\
\text {-Direkt temas }\end{array}$ & $\begin{array}{l}\text {-Anamnez } \\
\text {-Klinik muayene } \\
\text {-Oral eksfolyatif } \\
\text { sitoloji } \\
\text {-Vital doku } \\
\text { boyama } \\
\text {-Optik koherens } \\
\text { tomografi }\end{array}$ & $\begin{array}{l}\text {-Labial mu- } \\
\text { koza } \\
\text {-Yumuşak } \\
\text { damak } \\
\text {-Lingual } \\
\text { frenilum }\end{array}$ & $\begin{array}{l}\text {-Pembe, belirgin } \\
\text { sinırlı siğiller }\end{array}$ & $\begin{array}{l}\text {-Kondiloma } \\
\text { Lata } \\
\text {-Oral Verruka } \\
\text { Vulgaris } \\
\text {-Fokal Epitely- } \\
\text { al Hiperplazi }\end{array}$ & $\begin{array}{l}\text {-Oral hijyen } \\
\text { motivasyonu } \\
\text {-Tedaviler } \\
\text {-Bilgilendirme } \\
\text {-Konsültasyon }\end{array}$ \\
\hline
\end{tabular}


Erken evredeki lezyonların klinik görünümü; beyaz plak, kırmızı plak, kırmızı-beyaz plak ya da yüzeyel ülserler şeklinde olabilirken ileri evre lezyonlar; ülsere yüzeyli, iri nodül, kenarları düzensiz, kalkık ve ortasında fibrin birikimi bulunan şekilsiz oluşumlar şeklinde meydana gelebilir. Kazınamayan lezyonlar, fark edilir kitle lezyonları, çabuk büyüyen-sert-fikse lezyonlar, lokalize pigmente lezyonlar, boyunda yeni meydana gelmiş bir şişlik, kemik lezyonları, 4 haftadan uzun süren ve açıklanamayan orofasiyal ağrilar, orofasiyal hassasiyette azalma ve dişlerde 3 haftadan fazla süren, açıklanamayan mobilite gibi belirtilerin premalignmalign durumları işaret ettiği bildirilmiştir (31).

\section{Vital Doku Boyama}

Tolonyum klorit olarak da bilinen Toluidin mavisi nükleik asitleri boyayan vital doku boya maddesidir. Enflamatuar, rejeneratif ve neoplastik dokulardaki hızlı bölünen hücrelere ve oral malign/premalign lezyonlarla ilişkili olan deoksiribonükleik asitteki (DNA) farklılaşma olan alanlara bağlanabilmektedir. Hücre sitoplazmasındaki ribonükleik asit (RNA) ve hücre çekirdeğindeki DNA, toluidin mavisini sabitler. Boya, mitozun fazla olduğu hücrelerde nükleik asit tarafından tutulur ve dokunun koyu mavi görünmesini sağlar. Toluidin mavisi, malign ve premalign lezyon oluşma riski yüksek olan hastaları taramak için topikal ajan olarak veya gargara şeklinde de uygulanabilir. $(4,32)$ Gargara şeklinde kullanıldığında solüsyon oral kavitenin tamamını kapladığ için daha başarılı olmuştur (33). Bununla beraber, okul öncesi çocukların motor fonksiyonları gelişmekte olduğundan, gargara formu uygun değildir.

\section{Biyopsi}

Biyopsi; oral mukoza yüzeyinde önemli ve 1 srarcı bir renk değişikliği, görünümde proliferasyon, ülserasyon ve çatlama gibi bir değişiklik veya palpasyonda derin dokularda sert kitleler tespit edildiğinde gerekli olmaktadır.

Biyopside epitelyal displazinin derecesi ve bulunma nedeninin patolojik değerlendirmesi, oral mukozal premalign lezyonların malignite riskinin değerlendirilmesi için kullanılmaktadır. Düşük dereceli displazilerin çoğu kansere dönüşmezken yüksek dereceli displaziler eğer tedavi edilmezlerse sıklıkla kansere dönüşürler (34).

Premalign-malign lezyonların değerlendirilmesinde sıklıkla eksizyonel biyopsi tercih edilir (35). Eksizyonel biyopside lazer veya elektroknife kullanımından kaçınılmalıdır; bu teknikler, koagulatif artefakta sebep olur ve örneklerin değerlendirilmesini engeller. Premalign lezyonların biyopsilerinin, karakteristik kalın epitel örtüsü ve hiperkeratozdan dolayı, 4-5 mm derinlikte olması gerektiği bildirilmiştir (34) .

\section{Oral Eksfoliyatif Sitoloji}

Oral kanserlerin erken safhalarında genellikle asemptomatik oldukları, ödem, kanama, ülserasyon, servikal lenfadenopati gibi semptomlar vermedikleri bilinir. Araştırmalarda displazinin varlığ güvenilir yöntemin histopatolojik inceleme olduğu belirtilmiştir (35). Oral eksfoliyatif sitoloji sistemi (Oral
$\mathrm{CDx}{ }^{\circledR}, \mathrm{CDx}$ laboratories, Amerika), oral transepitelyal biyopsi sistemidir. Oral fırça biyopsisi ile alınan örneklerdeki hücrelerin, bilgisayar kullanılarak değerlendirilmesi şeklinde 1999 yılında kullanılmaya başlanmıştır. Eksfoliyatif sitoloji yöntemi, biyopsi ile kıyaslandığında, oral lezyonların teşhisinde invaziv olmayan, ağrısız, basit, hızlı, kabul edilebilir bir yöntem olup oral lezyonların teşhisi, benign yapıların doğrulanması ve premalign/malign lezyonların teşhisi amacıyla kullanılır $(4,36)$.

\section{Manyetik Rezonans Görüntüleme}

Manyetik rezonans (MRG) tekniğinde görüntülemenin oluşturulması, hastanın çok güçlü bir magnetin içine yerleştirilmesiyle sağlanmaktadır. Diş hekimliğinde; nazal kavitenin, paranazal sinüslerin, TME yapısı ve diskinin, lenf bezlerinin, kas ve yağ dokuları gibi anatomik yapıların yanı sıra çene kist ve tümörlerinin, orofasiyal yumuşak doku lezyonlarının ve benign-malign tümörlerin değerlendirilmesinde başarılı bir görüntüleme yöntemi olduğu belirtilmiştir (37).

\section{Ultrasonografi}

Kulağın duyamayacağı kadar yüksek frekanstaki ses dalgalarının bir bölümünün farklı yüzeylerden geçerken yansıması şeklinde çalışan görüntüleme yöntemidir. Ultrasonografi özellikle orofasiyal bölgedeki yabanc1 cisimlerin saptanmasında, orofasiyal kasların incelenmesinde, dilin değerlendirilmesinde, boyundaki lenf nodüllerinin incelenmesinde, postoperatif ödem ve hematomun değerlendirilmesinde, TME incelemesinde de kullanım alanı bulmaktadır (38).

\section{Optik Koherens Tomografi}

Işığın farklı yüzeylerden geçerken gösterdiği yansıma farklarının belirlenmesi ile biyolojik yapıların görüntülerini oluşturan bir görüntüleme yöntemidir (39) Dokularda biyolojik hasara neden olmadan görüntü oluşturduğundan çocuklarda da kullanılabilmektedir. Yumuşak doku birleşimi gibi anatomik yapıların lokalizasyonu, gingival dokulardaki morfolojik değişiklikler, diş çürüğü ve restorasyonlar ile ilgili bilgi edinilmesini sağladığı bildirilmiştir (13).

Okul öncesi çocuklarda görülebilen oral mukozal premalign lezyonların özellikleri, teşhis yöntemleri, ayırıcı tanıları ve gerekli klinisyen yaklaşımları, Tablo 2'de özetlenerek sunulmuştur.

\section{Sonuç}

Hastalar ile yakın temas halinde çalışan diş hekimlerinin, hastalıklar ve teşhisleri konusunda yeterli bilgi düzeyine sahip olmaları, bu anlamda hastalarına uygun yaklaşımlar sunmaları hekimlik vasıflarının bir gereği olarak ele alınmaktadır.

Diş hekimleri, hastaları özellikle de yüksek risk grubundaki hastaları oral mukozal premalign durumlar açısından ayrıntılı muayene etmeli, bu konudaki bilgi düzeyleri ve ekipmanları yeterli ise uygun teşhis yöntemleri kullanarak lezyonu değerlendirmeli, elde ettiği veriler ile hastayı ve ebeveyni bu konuda uzmanlaşmış bir merkeze yönlendirmeli ve olası risk faktörleri konusunda uyarmalıdır. Bilgilerin sürekli 
güncellenmesi, yeni teşhis yöntemi ve araçlarının takip edilmesi, hekimlerin farkındalık ve uygulama becerilerinin artmasında önemli bir faktördür.

Okul öncesi çocuklarda görülebilen oral mukozal premalign lezyonların ve teşhiste kullanılan yöntemlerin anlatıldı̆̆ bu derlemenin, klinisyenler için teşhis ve yaklaşımların planlanmasında fayda sağlayabileceği kanaatindeyiz.

\section{References}

1. Koç C. Kulak burun boğaz hastalıkları ve baş-boyun cerrahisi. In: Erpek MG, editör. Oral mukozal lezyonlar. 1. Bask1. Ankara, Güneş Kitabevi, 2004; 845-55.

2. Çelik O. Kulak burun boğaz hastalıkları ve baş boyun cerrahisi. In: Günbay S, Yücetürk AV, Kandiloğlu AR, editörler. Oral kavitenin mukozal lezyonları. 2. Baskı. İzmir, Asya Tip Kitabevi, 2007; 560-82.

3. Regezi JA, Sciubba JJ, Jordan RCK, editors. Oral Pathology: Clinical-Pathologic correlations. 6th ed. Philadelphia, Saunders, 1989.

4. Gillenwater A. Evaluation of oral premalignant lesions. In: Werning JW, editor. Oral cancer: diagnosis, management, and rehabilitation. New York, Thieme Medical Publishers, 2007; p. 31-7.

5. Pindborg JJ, Wahi PN, editors. Histological typing of cancer and precancer of the oral mucosa. 2nd ed. Berlin, Springer, 1997; p. 21.

6. Lingen MW, Chang KW, McMurray SJ, Kies MS, Mittal BB, Haines GK, Pelzer HJ. Overexpression of p53 in Squamous Cell Carcinoma of the tongue in young patients with no known risk factors is not associated with mutations in exons 5-9. Head Neck 2000; 22(4): 328-35.

7. Öztürk B, Coşkun U, Yaman E, Kaya AO, Yıldız R, Benekli M, Büyükberber S. Oral kavite kanserlerinde risk faktörleri, premalign lezyonlar ve kemoprevensiyon. UHOD 2009; 19(2): 118

8. Siegel MA. Premalignant lesions. In: Ord RA, Blanchaert $\mathrm{RH}$, editors. Oral cancer: The dentist's role in diagnosis, management, rehabilitation, and prevention. 1th ed. Illinois, Quintessence, 2000; p. 49-63.

9. Flaitz CM. Differential diagnosis of oral lesions and developmental anomalies. In: Pinkham JR, Casamassimo PS, Fields HW, Nowak AJ, Mc Tigue DJ, editors. Pediatric Dentistry: Infancy through adolescence. St. Louis, Missouri, Saunders, 2012; p. 11-53.

10. Arca E, Erbil AH, Taştan HB, Gür AR. Bir Diskeratozis Konjenita olgusu. Gulhane Med J 2003; 45(3): 281-4.

11. Harper JI. Genetics and genodermatoses. In: Champion RH, Burton JL, Burns DA, Breatnach SM, editors. Rook's Textbook of Dermatology. 6th ed. London, Blackwell Science Co., 1998; p. 357-436.

12. Kraemer KH. Heritable diseases with increased sensitivity. In: Freedberg IM, Eisen AZ, Wolff K, Austen KF, Goldsmith
LA, Katz SI, Fitzpatrick TB, editors. Dermatology in general medicine. 5th ed. New York, McGraw-Hill Company, 1999; p. 1848-62.

13. Soğur E, Akdeniz BG. Diş hekimliğinde yeni bir görüntüleme teknolojisi: Optik Koherens Tomografisi (OCT). GÜ Diş Hek Fak Derg 2005; 22(3): 195-200.

14. White MP, Goel KM, Connor JM, Coutts NA. Mucosal Neuroma Syndrome-a Phenotype for malignancy. Arch Dis Child 1985; 60(9): 876-7.

15. Yoshımoto K, Iwahana H, Itakura M. Relatively Good Prognosis of Multiple Endocrine Neoplasia Type 2B in Japanese: Review of cases in Japan and analysis of genetic changes in Tumors. Endocr J 1993; 40(6): 649-57.

16. Momeni A, Pieper K. Junctional Epidermolysis Bullosa: a case report. Int J Paediatr Dent 2005; 15(2): 146-50.

17. Fine JD, Eady RA, Bauer EA, Bauer JW, BrucknerTuderman L, Heagerty A, et al. The classification of inherited epidermolysis bullosa (EB): Report of the third international consensus meeting on diagnosis and classification of EB. J Am Acad Dermatol 2008; 58: 931-50.

18. Kirkham J, Robinson C, Strafford SM, Shore RC, Bonass WA, Brookes SJ, et al. The chemical composition of tooth enamel in junctional epidermolysis bullosa. Arch Oral Biol 2000; 45(5): 377-86.

19. Torres CP, Gomes-Silva JM, Mellara TS, Carvalho LP, Borsatto MC. Dental care management in a child with Recessive Dystrophic Epidermolysis Bullosa. Braz Dent J 2011; 22(6): 511-6.

20. Prabhu VR, Rekka P, Ramesh, Swathi S. Dental and Anesthetic Management of a Child with Epidermolysis Bullosa. J Indian Soc Pedod Prev Dent 2011; 29(2): 155-60.

21. Öncel MY, Ünal S, Yılmaz A, Yıldız J, Akbaş AY. Epidermolizis Bülloza tanısı alan yenidoğan olgu serisi. Turkish J Pediatr Dis 2011; 5(1): 5-10.

22. Fine JD. Inherited Epidermolysis Bullosa. Orphanet J Rare Dis 2010; 5: 12.

23. Rajendran R. Diseases of the skin. In: Sivapathasundaram B, editor. Shafer's text book of oral pathology. 8th ed. Lajput Nagar, New Delhi, Elsevier, 2016; p. 805-7.

24. Chaudhary M, Chaudhary SD, Gulhane A. Skin lesions in children. In: Chaudhary M, Chaudhary SD, editors. Essentials of pediatric oral pathology. 1st ed. New Delhi, Jaypee Brothers Medical Publishers, 2011; p. 318-20.

25. Ghaderi F, Hekmat S, Ghaderi R, Fardaei M. MSX1 Mutation in Witkop Syndrome; A case report. Iran J Med Sci 2013; 38(2): 191-4.

26. Kui LL, Xiu HZ, Ning LY. Condyloma Acuminatum and Human Papilloma Virus infection in the oral mucosa of children. Pediatr Dent. 2003; 25(2): 149-53.

27. Emmanouil DE, Post CA. Oral Condyloma Acuminatum in a child: Case report. Pediatr Dent 1987; 9(3): 232-5. 
28. Martin IC, Kerawala CJ, Reed M. The Application of Toluidine Blue as a diagnostic adjunct in the detection of Epithelial Dysplasia. Oral Surg Oral Med Oral Pathol Oral Radiol Endod 1998; 85(4): 444-6.

29. Epstein JB, Silverman S Jr, Epstein JD, Lonky SA, Bride MA. Analysis of oral lesion biopsies identified and evaluated by visual examination, Chemiluminescence and Toluidine Blue. Oral Oncol 2008; 44(6): 538-44.

30. Ram S, Siar $\mathrm{CH}$. Chemiluminescence as a diagnostic aid in the detection of oral cancer and potentially malignant epithelial lesions. Int J Oral Maxillofac Surg 2005; 34(5): 521-7.

31. Yıldırım B, Şengüven B, Barış E, Gültekin SE. Potansiyel malign Bozukluklar ve ağız kanseri şüphesi Bulunan Lezyonlara Yaklaşım ve Diş Hekimlerinin Erken Tanıdaki Rolü. ADO Klinik Bilimler Dergisi 2011; 5(2): 881-6.

32. Güneri P, Epstein JB, Ergün S, Boyacıŏlu H. Toluidine blue color perception in identification of oral mucosal lesions. Clin Oral Invest 2011; 15(3): 337-45.

33. Sadık E, Alkurt MT. Oral Mukozanın Şüpheli Lezyonlarının Teşhisinde Kullanılan Yardımcı Yöntemler.
GÜ Diş Hek Fak Derg 2012; 29(3): 201-8.

34. Poh CF, NG S, Berean KW, Williams PM, Rosin MP, Zhang L. Biopsy and histopathologic diagnosis of oral premalignant and malignant lesions. J Can Dent Assoc 2008; 74(3): 283-8.

35. Mota-Ramirez A, Silvestre FJ, Simo JM. Oral biopsy in dental practice. Med Oral Patol Oral Cir Bucal 2007; 12(7): 504-10.

36. Trullenque-Eriksson A, Munoz-Corcuera M, CampoTrapero J, Cano-Sánchez J, Bascones-Martínez A. Analysis of new diagnostic methods in suspicious lesions of the oral mucosa. Med Oral Patol Oral Cir Bucal 2009; 14(5): 210-6.

37. Erdem T, Aydın KC. Diş hekimliğinde kullanılan ileri görüntüleme teknikleri. Turk J Pediatr 2006; 96: 48-52.

38. Evlice BK, Öztunç H. Dijital radyografi ve diş hekimliğinde ileri görüntüleme yöntemleri. Arch Med Res 2013; 22(2): 230-8.

39. Jerjes W, Upile T, Conn B. In vitro examination of suspicious oral lesions using optical coherence tomography. Br J Oral Maxillofac Surg 2010; 48(1): 18-25. 